\title{
The utilization of methods based on protein and DNA analysis for identification of animal-origin components in feeds
}

\author{
M. Natonek', E. Slota, A. Żyga and B. Rejduch \\ National Research Institute of Animal Production, \\ Department of Animal Reproduction Biotechnology. Immuno- and Cytogenetics \\ Krakowska I, 32-1083 Balice, Poland
}

\begin{abstract}
The described methods are based on detecting protcin and mtDNA in feeds. Analyses targeting protein were based on ELISA tests, those detecting mtIDNA were conducted using PCR. The method based on analysing mtDNA permits identification of components of animal origin (porcine, ovine, bovine) and semi-quantitative estimation of DNA content. These characteristics make it suitable for routine control of feeds. E.LISA assays are less efficient for such analyses.
\end{abstract}

KEY WORDS: BSE, meat-and-bone meal, PCR reaction, ELISA

\section{INTRODUCTION}

Epidemiological studies have shown that feed mixtures containing animal meals are a potential source of BSE infection. The first and still-used method of detecting animal components in feeds is microscopic analysis that identifies fragments of bones, cartilages and hair in meat-and-bone meals (MBM). Due to the subjectivity of the test and the need to use model samples of feeds, many studies were undertaken to test the possibility of applying more reliable methods. Many laboratories developed methods based on protein and DNA analysis. Mcthods that use feed protein as an indicator of animal meals are based on ELISA, those focusing on DNA identification use the PCR reaction.

The aim of the experiment was to develop methods for identifying bovine, porcine and ovine components using ELISA and PCR techniques.

\footnotetext{
'Corresponding author: e-mail: mnatek(alzoo.krakow.pl
} 


\section{MATERIAL AND METHODS}

Samples of standardized feed mixtures containing 0,2 and 4\% MBM (meat and-bone-meal) of bovine origin (prepared at the Department of Animal Nutrition of the National Research Institute of Animal Production) were used in the experiment. Samples of feed mixtures containing 2 and $4 \%$ ovine and porcine meat meals made by mixing adequate proportions of the above meat meals with a standardized feed mixture containing no MBM were used. We made the meat meal in house using the technological process of commercial-scale MBM production (after Hahn, 1999), i.e. grinding raw meat, sterilizing the material by autoclaving at $140^{\circ} \mathrm{C}$ at $3 \mathrm{Ba}$ for $20 \mathrm{~min}$, centrifuging at $13000 \mathrm{rpm}$ for $5 \mathrm{~min}$, and mechanical removal of fat by pipetting.

In the first part of the experiment, the feed mixture containing bovine meal was analysed by ELISA. We applied the double ELISA test using anti-GFAP (glial fibrillary acid protein) antibodies (Momcilovic and Rasooly, 2000). GFAP cells are mainly found in the brain and spinal cord, and thus they should be a good indicator of the presence of components that pose the greatest threat of BSE. In the test we used polyclonal anti-GFAP antibody, monoclonal anti-GFAP Bovine Brain and anti-bovine IgG antibody IRP. The results were read out based on the colour intensity of the solutions in the wells. The negative control was expected to remain colourless, whereas samples with MBM were expected to change colour in proportion to their protein content.

In the second part of the experiment we identified bovine, ovine and porcine components based on identification of animal mtDNA. The isolated DNA was amplified in a PCR reaction, with the following concentrations of the mixture components: $10 \times$ Buffer - $1 \mathrm{x}$; dNTPmix - $0.5 \mathrm{mM}$; AmpliTaq Gold polymerase $0.05 \mathrm{U} / \mu \mathrm{l}$; gelatin $-0.04 \%, \mathrm{MgCl}_{2}-1.5 \mathrm{mM}$, eprimers $-0.32 \mathrm{pM}$. The primers used were described by Tartaglia et al. (1990) - for cattle and Lahiffet et al. (2001) for pigs and sheep. The amplification was carried out using the thermal program of $94^{\circ} \mathrm{C}$ $-5 \mathrm{~min} 30$ cycles $\left(94^{\circ} \mathrm{C}-1 \mathrm{~min}, 58^{\circ} \mathrm{C}-1 \mathrm{~min}, 72^{\circ} \mathrm{C}-1 \mathrm{~min}\right.$ ), $72^{\circ} \mathrm{C}-5 \mathrm{~min}$ (Lahiff et al., 2001). The PCR product was then analysed and identified by electrophoresis in $2 \%$ agarose gel with ethidium bromide.

\section{RESULTS}

Detection of animal components in feed mixtures by ELIS $\Lambda$ showed that the wells containing $0 \%$ meat-and-bone meal were not stained. The wells containing MBM were stained, but the $2 \%$ samples gave a more intense colour than the $4 \%$ samples.

The identification of animal components in feed mixtures by PCR is given in Figure 1. The gel image illustrating the results of electrophoresis shows that the 
PCR reaction between bovine primers and bovine mtDNA $(1,2)$ resulted in a $271 \mathrm{bp}$ product. Ovine mtDNA amplification with ovine primers $(7,8)$ gave a product of 225 bp. The amplification of porcine mtDNA $(13,14)$ gave a 212 bp product. Bands in the gel for feed mixtures containing $4 \%$ MBM were thicker than for the feeds containing $2 \%$ animal components. In the other cases, the PCR reaction gave no product.

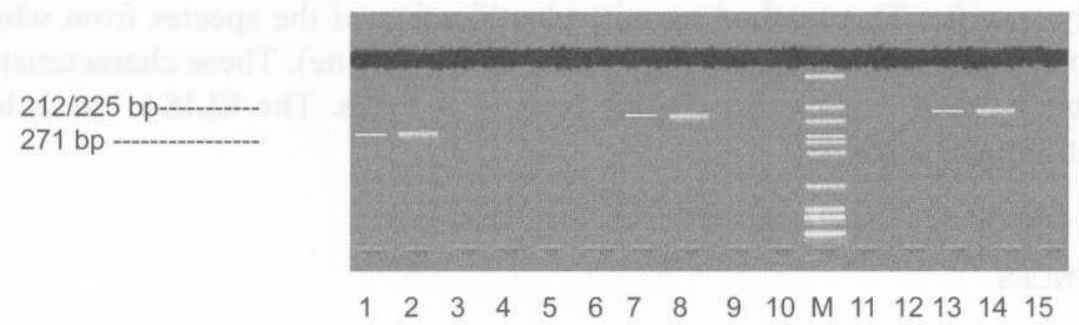

Figure.1 Gel image after electrophoresis: consecutive wells contain the PCR reaction product, in which were used bovine primers and bovine mtDNA ( $2 \%)(1)$, bovine mtDNA (4\%) (2), ovine mtDNA (3), porcine mtDNA (4), negative control (5), ovine primers and ovine mtDNA (6), ovine mtDNA $(2 \%)(7)$, ovine mtDNA $(4 \%)(8)$, porcine mtDNA (9), negative control (10), porcine primers and bovine mtDNA (11), ovine mtDNA (12), porcine mtDNA (2\%) (13), porcine mtDNA $(4 \%)(14)$, negative control (15)

\section{DISCUSSION}

This study was aimed at developing methods for detection of bovine, porcine and ovine components using ELISA and PCR. The use of antibodies did not yield the expected results. Although the negative control samples were not stained, which would point to the reliability of the samples, more intense staining was obtained for the $2 \%$ MBM samples than for the $4 \%$ MBM sample. This disqualifies the method. Such findings may arise from the use of heat treatment during MBM production, as a result of which protein in feed becomes denatured and forms aggregates, thereby obstructing the normal course of analysis, because the test requires a soluble antigen. The use of ELISA in this study was also hindered by the fact that antibodies often detect only part of the animal protein derived from specific tissues while disregarding other tissues, even of the same species (Chen and Hsieh, 2000), which may hinder mainly quantitative analysis. Further studies of the method were abandoned due to its shortcomings in detecting the bovine components.

Another method used was PCR. The results obtained suggest that this method is accurate, relatively quick ( 2 days) and sensitive. The experiment demonstrates that mtDNA of a species can only be amplified using primers characteristic of that species. This result is evidence that the applied primers are species specific and allow detecting highly processed components (Tartaglia et al., 1998; Lahiff 
et al., 2001). In addition, the thickness of bands in the gel was observed to be proportional to the content of the animal component.

\section{CONCLUSIONS}

The method for detecting animal meal added to feed based on mIDN $\Lambda$ analysis is highly specific. This method permits identification of the species from which the animal components originated (porcine, ovine, bovine). These characteristics make this method suitable for routine control of feeds. The ELISA test is less efficient for such analyses.

\section{REFERENCES}

Chen F.C., Hsieh Y.H., 2000. Detection of pork in heat-processed meat products by monoclonal antibody-bascd ELISA. J. Assn. Off. Anal, Chem, Int. 83, 79-85

Hahn H., 1999. Animal meal: production and determination in leedstuffs and the origin of bovine spongiform encephalopathy. Naturwissenschaften $86,62-70$

Lahiff S., (Glennon M., O'Brien L., Lyng J., Smith T., Maher M., Shilton N.., 2001. Species-specific PCR for the identification of ovine, porcine and chicken species in meat and bone meal (MBM). Mol. Cell. Probe. 15, 27-35

Momcilovic D., Rasooly A., 2000. Detection and analysis of animal materials in food and feed. J. Food Protect. 63, 1602-1609

Tartaglia M.. Saulle E., Pestalozza S., Morelli R., Antonucci G., Bataglia P.A., 1998. Delection of bovine mitochondrial DNA in ruminant feeds: a molecular approach to test for the presence of bovine-derived materials. J. Food Protect. 61, 513-518

\section{STRESZCZFNIE}

\section{Wykorzystanie metod opartych na analizie bialek i DNA do identyfikacji skladników pochodzenia zwierzęcego $\mathrm{w}$ paszach}

Metody te opierają się na identyfikacji bialka i mIDNA w pas zach. Białko oznac/ono testem ELISA, a mtDN $\Lambda$ analizowano metoda PCR. $\angle$ badań jednoznacznic wynika, że metoda PCR pozwala na dokładne rozróznienie składników pochodzących od różnych gatunków zwicrząt (świń, owiec, bydla) i ich pólilościową analizę. Opisywana metoda nadaje się do rulynowej kontroli pas

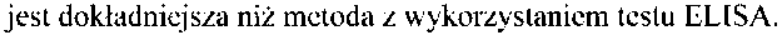

